\title{
Thermal Etching of Silver
}

\author{
Toshio SUZUKI*
}

The surface of many metals, initially smooth, are found to turn into a characteristic striated one when heated at a temperature very near to their melting points in a suitable atmosphere. The phenomenon of thermal etching has been investigated most extensively on silver ${ }^{1-4}$, though it has been also observed with many other metals such as copper, platinum, cadmium, etc ${ }^{5}$. Thermal etching of silver occurs readily when heated in air at atmospheric pressure for a few hours.

The purpose of this note is to report some observation on thermally etched surface on silver single crystal. The pattern of thermally etched surface on silver is usually very complicated. After the formation of linear ridges (primary etching), the plane (complex plane) which does not correspond to a simple crystallographic plane is expected to break up into a hill and valley structure with a new simple plane and a new complex plane. This secondary etching has been reported on silver ${ }^{2)}$. The new complex plane again breaks up into a newer simple plane and a newer complex plane. This etching process is repeated alternatively and finally the surface consists of the planes (111), (100) and the newest complex plane.

The example of this type is generally observed in the middle of the process in thermal etching as shown in Photo. 1.

The simultaneous development of the planes (111) and (100) has been found. The complex planes are very complicated and tilted at various inclinations. Moore $^{2)}$ has pointed out that by alternating process of thermal etching a new complex plane is always left on the etched surface. But it was observed in the present observations that some area of the original surface broke up into the simple planes and no complex plane appeared. This typical area is shown in Photo. 2.

From this result, it can be concluded that the com- plex planes are appreciably unstable and tend to break up into the simple crystallographic planes, as thermal etching develops.

On the basis of the above results, the process of thermal etching may be shown as follows :

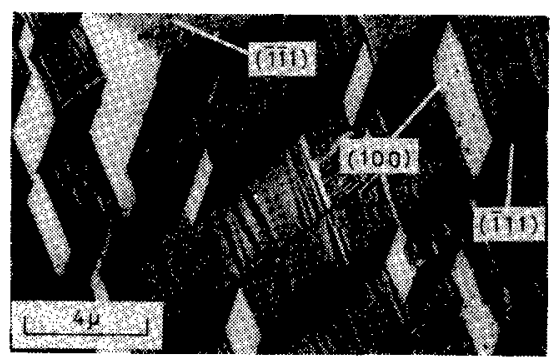

Photo. 1 Thermally etched pattern produced on the surface inclined at angle of $26^{\circ}$ to the (111) plane

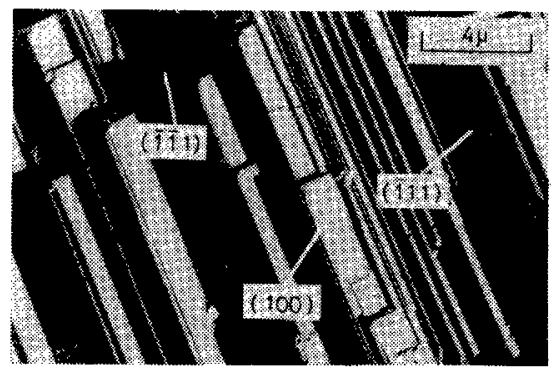

Photo. 2 Thermally etched pattern produced on the surface inclined at angle of $17^{\circ}$ to the (111) plane. The etched surface was covered with only simple planes

- Institute of Atomic Energy, Kyoto University (Uji,Kyoto) 


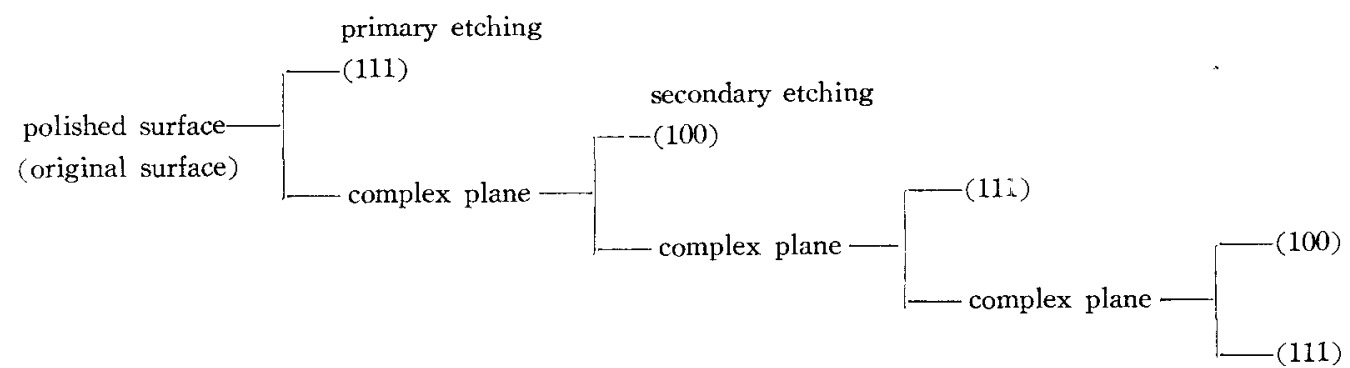

(Received July 26,1972)

References :

1) B. Chalmer, R. King and R. Shuttleworth, Proc. Roy. Soc. A $193,465(1948)$.

2) A.J.W. Moore, Acta Metallurgica 6, 293 (1958).
3) E.D. Hondros, A.J.W. Moore, ibid. 8, 647 (1960).

4) G.E. Rhead, H. Mykura, ibid. 10, 843 (1962).

5) B.D. Cuming, A.J.W. Moore, J. Aust. Inst. Met. 3, 124 (1958).

\section{污会誌「電気化学および工業物理化学」英文要旨の曺き方々}

\section{1. 英文要白のまとめ方}

英文要旨は 200 語以内にまとめるものとし，論文の内容小よ び結諭の要的で，新情報や新知見を読者に示し得るものとす

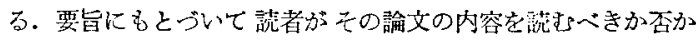
の判断ができるようにしなければならない，穴のためには次の 啫点に留意して諭文の主眼となる項目を中心に記述すること。

i）研究の目的怙よび範围が表題から明らかに理解できる 場合注，要旨の中にそれを繰り返えさないこと．表題に よって内容を明確に表現しきれないときは，研究の目的 オよびその概要を示すこと。

ii）新らしい考元方, 理論, 研究方法, 装置, 反応, 物啠, データー（精度を含めて），既存の知識の新分野への心用 など、研究上新らしい点岁述へること。

iii）实験方法について䉮単に述へること。

iv）研究結果一新事実を強調する一

v）研究結果についての著者の考察.

vi）たと文主題から離机ていても新発兒については言及す ること.

\section{2. 英文を作成するときの注意}

（1）文案山簡潔な 表現を用いること．しかし 完全な文章て なければならない。電文のような見出語の玀列ではいけない。

(2) [国際的に認められている略号や用語以外を用いないと と. 宗无固有名，商品名ではなく一般名を用いること。

(3) 英文要旨 それ自身で内容の豊富なものであること. 数 宁はどを用いて本文や文献からの引用は原則として避けること.

(4) 文至のスタイルは「われわれは……..女行なった（We ……)」としないで，第三者的に[……...多行なわれた」とするこ

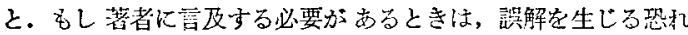
がない限り三人称とすること（we とはしないで the author (s) のように).

(5) 冠詞を適切に用いることにより文章を明確にすること.

(6) フラピ数字は支頭に用いないこと.また As, He, I, Inのようにまきりうしい元素記号も文頭に用いないこと。

(7) 動佩はなるべく主語に近い位置におく方がわかりやす い.
（8）時制治現在形，過去形，現在完了形などを用いるが， とくこつの場合を除いては，時制注混合して用いない方が良い。 原則的には之の論文中で行なっている動作は現在形を（…… is discussed....... is described.......is shown.), 実験內容として 行なった過去の動作は過去形を用いる（the mixture was distilled). しかし研究の全般的な目的にかかわる動作には現在, 過志形のほ加, 現在完了形流用いても良い(……has been studied,…h.has been developed.). 結果, 絬論については過去, 現在のいずれを用いても良いが，過去を用いた場合は単に結果 を紹介する感しであるのに㳔して，現在を用いるとちの結果が 不変の事実であるとの強い感じとなることが多い

(9) 主語が単数から複数に変化するような重文においては,

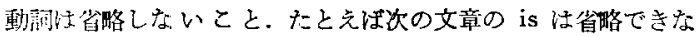
w.

The two liquids are mixed and the mixture is heated to boiling

（10）物の単位を示すような 集合名詞は 単数動詞をとるこ そ. “ $10 \mathrm{~g}$ are added”ではなく, “ $10 \mathrm{~g}$ is added." data とか, spectra のように複数名詞は複数動詞をとる.

（11）䊝垂分詞（文の主語と文法的に結合されないまま用い られている分詞）は用いない方が良い。たとえば“N was determined using the kjeldahl method." ではなく, “N was determined by the kjeldahl method." とすること.

(12） 3 ュ以上の言葉をならへて用いる埸合, 最後の 2 語老 結ぶ“and”, “or”, “nor” の前にはカンマをつけること。

"benzene, toluene, and xylene."

"either Cu, Ag, or A.u."

(13) 本誌の要旨においてはパラグラフは設けないことにる(己行を行わない).

一参考文献-

1. UNESCO "Guide for the preparation and publication of synopses" (1949).

2. ISO Recommendation R 214 " Abstracts and synopses" (1961).

3. Chemical Abstracts "Direction for abstractors" 